УДК 343.236 .4

DOI https://doi.org/10.32849/2663-5313/2019.12.54

\title{
Олександр Капустін,
}

адвокат, аспірант кафедри кримінального права

Національного університету «Одеська юридична академія»

\section{УМИСЕЛ У СКЛАДІ ЗЛОЧИНУ}

Стаття поглиблює вчення про умисел як частину злочину. Констатовано, що питання умислу висвітлені в науковій літературі недостатньо, при иьому тематика умислу як частини злочину в останніх публікаиіях окремо не розглядається. Такожу теорії кримінального права немає однозначної думки з приводу формування (виникнення) умислу $і$ його віднесення до частини вчинення злочину. Одні вчені виділяють умисел як частину вчинення злочину, інші ж виступають проти віднесення його до стадій вчинення злочину. Отже, окреме висвітлення цього питання є прогалиною в сучасній науиі і його дослідження має наукову новизну. Заповнити зазначену прогалину має на меті ия стаття.

Злочином, вчиненим умисно, визнається Әіяння, вчинене з прямим або непрямим умислом. Умисні злочини є найбільш небезпечними злочинами. При иьому більшість злочинів, передбачених нормами кримінального законодавства, належить до умисних. Відмічено, шо первісним етапом злочину є виникнення умислу, який спочатку часто не має якого-небудь зовнішнього прояву. Перед скоєнням певного злочинного діяння у свідомості особи складається в загальних рисах уявлення про сутність злочину, про способи його здійснення, формується психологічне ставлення до майбутнього злочинного діяння, до злочинного результату у формі бажання досягнення злочинної мети. Під час формування умислу розумова діяльність особи не знаходить свого прояву в зовнішньому світі, не становить реальної небезпеки для об'єкта злочину, на ивому етапі відсутня реальна загроза заподіяння шкоди інтересам особистості, суспільства або держави. Свідома діяльність особи на стадії формування умислу не має самостійного кримінально-правового значення $i$ не є караною. Однак, якщо особою вчиняються наступні дї, спрямовані на реалізацію сформованого раніше злочинного наміру, $і$ вони утворюють суспільно небезпечне діяння, що заподіює шкоду або створює реальну загрозу заподіяння шкоди суспільним відносинам, благам та інтересам, шо охороняються правом, тобто якщо сформоване психічне ставлення до майбутнього злочинного діяння $i$ до його наслідків знаходить свій зовнішній прояв або на стадії готування до злочину, або на стадії умисного скоєння дій (бездіяльності), безпосередньо спрямованих на вчинення злочину, - в иьому випадку формування умислу слід визнати початковим етапом злочину. Встановлено, шо формування умислу і його виявлення за умови обов'язкової наявності хоча б однієї з наступних стадій в процесі розвитку злочинної діяльності слід віднести до безкарних стадій розвитку злочину. Необов'язково, шоб усі етапи розвитку злочинної діяльності були караними. При иьому, коли йдеться про вже закінчений злочин, велике практичне значення має дослідження формування умислу, шо допомагає розкрити сутність злочину в динаміці. Зазначено, що перспективами подальших досліджень у цьому напрямі $є$ проблема адекватного законодавчого відображення небезпеки умислу.

Ключові слова: стадія злочину, незакінчений злочин, закінчений злочин, готування до злочину, злочинна поведінка, злочинний намір.

Постановка проблеми. Умисел - відома в юриспруденції правова категорія. Згідно 3 Кримінальним кодексом України злочином, вчиненим умисно, визнається діяння, вчинене з прямим або непрямим умислом.

Відомо, що більшість злочинів, передбачених нормами кримінального законодавства, належить до числа умисних. До них належить і більшість злочинів, скоєних у житті. Умисні злочини є найбільш небезпечними злочинами, і з огляду на це вони привертають найбільшу увагу працівників правоохоронної сфери, викликають найбілыше обурення громадськості.

Аналіз останніх досліджень і публікацій. Незважаючи на це, питання умислу висвітлені в науковій літературі дуже слабко. За останні 25 років відсутні вітчизняні дослідження на дисертаційному та монографічному рівнях, присвячені розгляду умислу. Існують лише фрагментарні звертання до цього поняття у дослідженні різних дотичних тем. Такий стан справ є характерним і для наукових статей. Серед останніх публікацій на цю тему можна згадати наукові розвідки А.В. Бойка [1], Р.В. Вереши [2], Р.С. Сергєєва [3], О.В. Церковної [4]. Проте і в них тематика умислу як частини злочину окремо не розглядається. Тож окреме висвітлення цього питання є прогалиною в сучасній науці 
і має наукову новизну. Заповнити зазначену прогалину має на меті ця стаття.

Метою статті $\epsilon$ науковий розгляд і юри॥ дичний аналіз умислу як частини злочину.

Виклад основного матеріалу. У теорії кримінального права немає однозначної думки з приводу формування (виникнення) умислу і його віднесення до частини вчинення злочину. Одні вчені виділяють умисел як частину вчинення злочину, інші ж виступають проти віднесення його до стадій вчинення злочину.

Будь-яка осудна особа, в тому числі й злочинець, перш ніж перейти до певних дій, спочатку діє подумки. Перед скоєнням певного злочинного діяння у свідомості особи складається в загальних рисах уявлення про сутність даного злочину, про способи його здійснення, формується психологічне ставлення до майбутнього злочинного діяння, до злочинного результату у формі досягнення злочинної мети. Усі ці процеси, що відбуваються у свідомості особи, можна назвати формуванням умислу. Уваги заслуговує визначення, дане М. Алленом, згідно з яким формування умислу являє собою свідомо-вольовий процес моделювання особою майбутньої злочинної поведінки [5, с. 142]. Так, формування умислу являє собою свідомо-вольовий процес, оскільки на стадії виникнення умислу в особи формується психічне ставлення не тільки до злочинного діяння, а й до наслідків, які виникнуть у результаті вчинення цього діяння, оскільки будь-яка свідома дія (бездіяльність) осудної особи здійснюється з певною метою. Вже далі особа робить певні дії для досягнення своєї злочинної мети, якщо вона бажає її досягти.

Так, Р. Вереша до частини вчинення злочину відносить виникнення умислу (намір), підготовку злочинного діяння, саме злочинне діяння і результат [6, с. 1883]. Первісним етапом $є$ виникнення умислу, наміру, що являє собою чисто внутрішній процес свідомості та не знаходить якої-небудь реалізації чи навіть виявлення назовні.

Зарубіжні вчені також виділяють формування умислу як перший етап вчинення злочину, коли суб'єкт створює інтелектуальну й психічну можливість скоєння злочину, проте цей етап є байдужим для суду в силу того, що мається на увазі під караністю дій. Оскільки формування умислу є чисто психічним процесом, який ще не є дією, воно не може бути караним і тягнути за собою кримінальну відповідальність [7, с. 185].

B.M. Бурдін також виділяв формування умислу як стадію вчинення злочину поряд iз приготуванням до злочину, замахом на злочин і закінченим злочином [8, с. 29]. Н.Д. Дурманов визнавав помилковим включення формування умислу в число стадій і стверджував, що можна говорити про стадії здійснення злочину тільки в тих випадках, коли є акт зовнішньої поведінки, без якого взагалі не може бути мови про встановлення тих чи інших процесів, що протікають у свідомості людини [9, с. 80]. На думку автора, визначаючи стадії, що передують закінченому злочину, треба зупинятися тільки на тих етапах здійснення умисного злочину, які виразилися в конкретній зовнішній дії, нерозривно поєднують об'єктивні та суб'єктивні моменти (умисел, мотив), тому виключаються чисто внутрішні процеси свідомості, натомість відбувається поява відповідних мотивів, формується намір [9, с. 82].

В.П. Тихий є прихильником виділення виникнення задуму як самостійної стадії вчинення злочину. На думку автора, два етапи неодмінно присутні в кожному злочині: виникнення психологічних відносин, які обов'язково передують злочинній поведінці, і діяння, яке створює умови або заподіює шкоду суспільним відносинам чи ставить їх під загрозу заподіяння шкоди; інші стадії можуть бути або присутніми, або відсутніми у скоєному злочині [10, с. 28]. Ю.М. Антонян виділяе обов'язковий у всіх злочинах етап розвитку злочинного діяння: формування психологічних ставлень обов'язково передує злочинній поведінці та діянню, що завдає шкоди суспільним відносинам, або створює умови для нанесення такої шкоди, або ж ставить ці відносини під загрозу нанесення шкоди [11, с. 114]. Формування умислу не може бути предметом кримінально-правових відносин, оскільки загальновизнаний принцип кримінального права зазначає: «cogitationis poenam nemo patitur» $[12$, c. 6$]-$ «думки не караються».

Як правильно вказується в юридичній літературі, особа не може бути притягнута до відповідальності лише за думки, в тому числі і злочинні, якщо вони не проявилися в конкретному діянні. Під час формування наміру розумова діяльність особи не знаходить свого прояву в зовнішньому світі, не становить реальної небезпеки для об'єкта злочину, на цьому етапі відсутня реальна загроза заподіяння шкоди інтересам особистості, суспільства або держави. Свідома діяльність особи на стадії формування наміру не має самостійного кримінально-правового значення і не є караною.

Однак, якщо особою вчиняються наступні дії, спрямовані на реалізацію сформованого раніше злочинного наміру і вони утворюють суспільно небезпечне діяння, що заподіює 
шкоду або створює реальну загрозу заподіяння шкоди суспільним відносинам, благам та інтересам, що охороняються правом, тобто якщо сформоване психічне ставлення до майбутнього злочинного діяння і до його наслідків знаходить свій зовнішній прояв або на стадії готування до злочину, або на стадії умисного скоєння дій (бездіяльності), безпосередньо спрямованих на вчинення злочину, - в цьому випадку формування умислу слід визнати початковим етапом злочину. Формування умислу за обов'язкової наявності хоча б однієї з наступних стадій в процесі розвитку злочинної діяльності є безкарною стадією розвитку злочину, але не стадією його здійснення, оскільки можна говорити про вчинення злочину тільки в тому випадку, коли розумова діяльність особи знаходить свій зовнішній прояв, думки проявляються в конкретному діянні.

Поділяємо позицію А.П. Козлова [13, с. 41], згідно з якою вченим і юристам, які не виділяють формування умислу як стадію вчинення злочину, не слід посилатися на неможливість відповідальності за думки, неможливість притягнення до кримінальної відповідальності на цій стадії, оскільки в такому випадку вони змішують предмети дискусії: проблеми динаміки розвитку злочину й проблеми відповідальності за незакінчений злочин, переводять дискусію в площину видів незакінченого злочину, де змішуються стадії та види незакінченого злочину.

Формування наміру може супроводжуватися інформуванням інших осіб про бажання скоїти злочин і в такому випадку є виявленням умислу. На цьому етапі особа усно, письмово або в інший спосіб (наприклад, за допомогою рухів тіла) ділиться з іншими особами своїм наміром здійснити злочинне діяння, виражає ставлення до власних дій, розуміння об'єктивного розгортання злочину від діяння до наслідків, сподіваючись таким чином визначити ставлення оточуючих до майбутнього злочинного діяння.

А.А. Піонтковський виділяв виявлення наміру як самостійну стадію злочину, обгрунтовуючи свою позицію тим, що «хоча виявлення наміру не має суспільно небезпечного характеру, однак голий умисел переслідує свої самостійні цілі і є засобом безпосереднього посягання на охоронювані законом інтереси, а отже, є стадією в розвитку умисної злочинної діяльності» [14, с. 403]. Прихильником віднесення виявлення умислу до стадій злочинної діяльності був і В.М. Литвішков [15, с. 72].

А.П. Козлов також визнає виявлення задуму стадією вчинення злочину, розумі- ючи під цим повідомлення певного оточення, виражене в різних формах, про суспільнонебезпечний задум. Автор вважає, що в багатьох випадках виявлення задуму є не тільки межею, за якою слідує співучасть, але й прелюдією, підготовкою співучасті [13, с. 45].

Проти виділення виявлення умислу як частини злочину виступали ряд вчених. Так, Н.Д. Дурманов під виявленням умислу також розумів вираження зовні тим чи іншим способом наміру вчинити злочин і стверджував, що виявлення наміру, на відміну від формування умислу, що є тільки актом свідомості, - це конкретна дія, але дія, що не являє собою якогось руху шляхом скоєння злочину. Автор не відносив виявлення наміру до частини розвитку злочину й обгрунтовував свою позицію тим, що дія, яка, можливо, згодом утворить злочин, є свідомою діяльністю, спрямованою на певний об'єкт, тоді як у разі виявлення умислу дії, якими виявлено умисел, за загальним правилом, не адресовані тому самому об'єкту, що й об'єкт майбутнього злочину, а єдність об'єкта - характерна особливість усіх стадій вчинення даного злочину [9, с. 21]. Більш розгорнуту аргументацію того, що виявлення задуму не $є$ частиною вчинення злочину, дала Н.В. Маслак. На її думку, у разі виявлення умислу суб'єкт не створює ніяких сприятливих умов виконання злочину; виявлення наміру не перебуває ані в зумовлюючому, ані в причинному зв'язку з вчиненням злочину; єдиним наслідком виявлення умислу є те, що сторонні особи дізнаються про злочинний намір суб'єкта; виявляючи умисел, винний не наближає наслідки, а відсуває їх, оскільки наражає себе на загрозу викриття [16].

М.В. Гринь дотримується тієї позиції, що виявлення наміру не є частиною скоєння злочину і будь-яке кримінальне переслідування виявлення наміру $є$ неприйнятним. Автор пише: «Не має кримінально-правового значення виявлення наміру, що виразилося в словах, письмово, в конклюдентних діях. Заявлений (в усній чи письмовій формі) задум - ще не початок втілення злочинного наміру. У цьому випадку немає головного елемента, з яким пов'язується настання кримінальної відповідальності, - здійснення будь-якого суспільно-небезпечного діяння, спрямованого на фактичне вчинення злочину. Виявлення наміру не ставить об'єкти, що охороняються, в небезпеку заподіяння шкоди. У виявленні умислу відсутня основна матеріальна ознака злочину - його суспільна небезпека» [17]. Л.М. Федорак також дотримується тієї позиції, що формування і виявлення наміру не є частиною вчинення злочину, оскільки підставою кримінальної 
відповідальності є вчинення суспільно небезпечного діяння, що заподіює шкоду або створює реальну загрозу заподіяння шкоди інтересам особистості, суспільства або держави [18, с. 46]. С.О. Сафронов також вважає, що виявлення наміру не можна розглядати як частину вчинення злочину, оскільки за Кримінальним кодексом такі дії не тягнуть кримінальної відповідальності [19, с. 202].

Інші вчені також не визнають частиною і не вважають злочинним і караним виявлення наміру, пов'язуючи це з тим, що в основу кримінальної відповідальності покладається тільки діяння, небезпечне в зовнішньому вираженні, тобто небезпечне для інтересів особистості, суспільства і держави. Дійсно, все, що не втілено у діянні, перебуває поза межами кримінально-правового регулювання і не може спричиняти кримінальну відповідальність.

Думка про те, що виявлення наміру не може бути віднесено до частини вчинення злочину, виглядає слушною, адже, по-перше, під час інформування інших осіб про намір вчинити злочин зовнішня форма прояву виявлення наміру ще не утворює суспільнонебезпечного діяння, яке зазіхає на об’єкт кримінально-правової охорони; по-друге, виключною підставою для кримінальної відповідальності виступає вчинення злочину, а це - діяння, що містить у собі усі ознаки складу злочину, що передбачено кримінальним правом. Але виявлення наміру слід визнати некараним етапом розвитку злочинної діяльності лише в тому разі, якщо надалі не відбувається саме злочинне діяння. Обов'язкова наявність хоча б однієї 3 наступних стадій в процесі розвитку злочинної діяльності свідчить про те, що особа не обмежилася одним лише вираженням бажання, намірів вчинити злочинне діяння, а вчинила конкретні дії, спрямовані на реалізацію свого наміру.

За наявності залежних або незалежних від волі особи обставин їі діяльність може обмежитися лише виявленням наміру, і в цьому випадку діяльність особи на стадії виявлення наміру не має самостійного кримінально-правового значення. Наприклад, коли особа ділиться наміром вчинити крадіжку грошей зі своїм другом і далі не робить ніяких реальних дій для реалізації свого наміру, тому що або його друг відмовляє його від цього, або він сам вирішує зупинитися i не ризикувати заради такої суми, то його дії не є злочинними і караними, а виявлення наміру не є стадією розвитку злочину. Інша річ, коли особа після того, як поділилася зі своїм другом наміром вчинити крадіжку грошей, приступає до здійснення злочинного діяння. У цьому випадку умисел є частиною злочину і виявлення наміру слід віднести до стадій розвитку злочинної діяльності тому, що за наявності залежних або незалежних

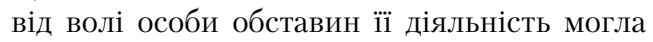
б зійти нанівець на стадії виявлення наміру та не перейти в наступну. На цій стадії розвитку умисного злочину ще немає заподіяння шкоди та відсутня матеріальна ознака злочину - суспільна небезпека.

Слід звернути увагу на ще один важливий момент: 3 якою метою особа виявляє свій умисел: 1) намагається через інформування інших осіб визначити іхне ставлення до потенційного злочинного діяння, дізнатися їхню позицію з цього приводу; 2) або ж це інформування необхідно для подальшого розгортання злочинної діяльності особи і проводиться 3 певною метою - отримати корисну інформацію, пораду чи яку-небудь допомогу, залучити спільників вчинення злочину тощо. В останньому випадку дії особи можуть сприяти покращенню умов для вчинення злочину, також при цьому виникає необхідність відмежування стадії виявлення наміру від стадії готування до злочину.

Проблема полягає в тому, що перелік підготовчих дій за кримінальним кодексом не $€$ вичерпним, у законі йдеться про умисне створення інших умов для вчинення злочину, що викликає додаткові труднощі як у встановленні таких умов, так і в їх відмежуванні від виявлення умислу. Інститут стадій вчинення злочину служить, таким чином, тим самим цілям та інтересам, що й формально-матеріальне визначення поняття злочину, - визначенню меж злочинного і караного діяння. Наслідком невичерпного переліку видів караних підготовчих дій $є$ відсутність певних критеріїв відмежування стадії виявлення наміру від стадії готування до злочину, в результаті чого неможливо чітко визначити, чи належить діяльність особи до некараної діяльності на стадії виявлення умислу або ж дії особи утворюють карані підготовчі дії, виражені в навмисному створенні умов для здійснення злочину. В якості такого критерію законодавець називає умисне створення умов. У зв'язку з цим можна дійти висновку, що змістова сторона даного критерію потребує уточнення, оскільки умови для вчинення злочину можуть мати різне значення: бути необхідними і випадковими, істотними і супутніми, що визначають обставини вчинення злочину або приховування його слідів, об'єктивними чи суб'єктивними тощо.

У кримінальному законодавстві, крім іншого умисного створення умов, окремо виділяється також підшукання співучасників злочину і змова на вчинення злочину. 
Тільки у разі виявлення умислу стає можливою співучасть, допомога з боку інших осіб у вчиненні злочину, а якщо інформування інших осіб про намір здійснити злочинне діяння проводиться саме 3 такою метою, то дії особи утворюють підготовчі дії. Однак, як справедливо відзначається в юридичній літературі, «включення в межі незакінченого злочину змови як самостійного етапу здійснення посягання щонайменше некоректно в правовому відношенні» [20, с. 357]. Змова на вчинення злочину передбачає домовленість двох або більше осіб вчинити злочин, досягнення угоди між останніми, при цьому між учасниками змови не відбувається жодних інших дій. Змова є варіантом виявлення умислу, яке законом не згадано в числі варіантів незакінченого злочину. У конкретних складах як самостійний вид злочину змова не передбачена, в числі форм співучасті вона також відсутня. Таким чином, оскільки згідно зі ст. 2 КК України [21] підставою відповідальності за кримінальним кодексом $€$ вчинення діяння, що має усі ознаки складу злочину, передбаченого КК, видається правильним підходом виключення із законодавчого визначення такої форми об'єктивної сторони готування до злочину, як змова на вчинення злочину. Цю позицію можна обгрунтувати тим, що під час змови виникає тільки намір вчинити злочин, а для приготування до злочину не досить наявності тільки умислу - необхідно, щоб він був утілений в діяння (дії або бездіяльність).

Готування - цілеспрямована діяльність, вчинювана свідомо. У ній починає реалізовуватись умисел на вчинення злочину. Тому створити умови для злочинного посягання без прямого умислу неможливо. У разі непрямого умислу, умислу неконкретизованого, тим більше у разі необережної форми вини шкідливі наслідки об'єктивно і суб'єктивно не є неминучими, а є ймовірними [22, с. 52].

Виявлення наміру не слід змішувати 3 однією з форм психологічного примусу (насильства) - загрозою, коли конкретний прояв наміру на злочин або є дією, яка заподіює або здатна завдати шкоди певним цінностям, або виступає як спосіб вчинення іншого злочину. У кримінальному кодексі містяться склади злочинів, які з об'єктивної сторони характеризуються загрозою, психологічним примусом. Наприклад, стаття 129 КК України «Погроза вбивством» встановлює відповідальність за погрозу вбивством, якщо при цьому була реальна небезпека здійснення цієї погрози; стаття 350 «Погроза або насильство щодо службової особи чи громадянина, який виконує громадський обов'язок» встановлює відповідальність за насильство, яке небез- печне для життя чи здоров'я, або загрозу його застосування стосовно представника влади (службової особи, громадянина, що виконує службовий обов'язок) або його близьких у зв'язку з виконанням ним своїх службових обов'язків та ін. В інших складах злочину загроза є способом вчинення злочину (ст. 146 «Незаконне позбавлення волі або викрадення людини», ст. 152 «Згвалтування», ст. 157 «Перешкоджання здійсненню виборчого права або права брати участь у референдумі, роботі виборчої комісії або комісії з референдуму чи діяльності офіційного спостерігача», ст. 187 «Розбій» тощо).

Як уже зазначалося, метою виявлення умислу є тільки доведення до відома третіх осіб намірів особи вчинити злочинне діяння, під час виявлення умислу не порушується жоден 3 охоронюваних кримінальним правом об'єктів, тоді як загроза являє собою психологічне насильство над жертвою 3 метою зміни ії поведінки в інтересах того, хто загрожує, в потрібному йому напрямі, являє собою суспільно небезпечне діяння, оскільки вона перешкоджає реалізації громадянами гарантованих Конституцією [23] прав і свобод. Видається правильним те, що у разі загрози насправді карається не намір, а суспільно небезпечне діяння - загроза, навіть якщо у погрожуючого і немає жодного наміру надалі реалізувати їі.

\section{Висновки}

Таким чином, дана стаття поглиблюе вчення про умисел як частину злочину. Виходячи 3 викладеного, формування умислу і його виявлення за обов'язкової наявності хоча б однієї з наступних стадій в процесі розвитку злочинної діяльності слід віднести до безкарних стадій розвитку злочину. Необов'язково, щоб усі етапи розвитку злочинної діяльності були караними. Так, згідно з кримінальним законодавством приготування до злочинів невеликої та середньої тяжкості може бути безкарним діянням, однак це не означає, що період здійснення таких підготовчих дій перестає бути частиною злочину. Коли справа стосується вже закінченого злочину, то не можна заперечувати важливу практичну значимість формування умислу та його виявлення, що досить повно допомагає розкрити сутність злочину в динаміці, ступінь його суспільної небезпеки.

Ця стаття не відображає всі законодавчі та юридичні аспекти умислу. Перспективою подальших досліджень є, зокрема, проблема адекватного законодавчого відображення небезпеки умислу. 


\section{Список використаних джерел:}

1. Бойко А.В. Непрямий умисел при вчиненні насильства щодо працівника правоохоронного органу. Актуальні проблеми держави і права. 2012. Вип. 67. С. 631-637.

2. Вереша Р.В. Умисел і його види (коментар до ст. 24 КК України). Вісник Академї адвокатури України. 2010. № 3. С. 73-82.

3. Сергєєв Р.С. Умисел та необережність в адміністративних проступках у сфері енергозбереження. Право і суспільство. 2011. № 5. С. 87-90.

4. Церковна О.В. Умисел потерпілого як підстава звільнення заподіювача від завданої ним шкоди. Університетські наукові записки. 2010. № 4. С. 63-68.

5. Allen M. Textbook on Criminal Law. Oxford, $2013.580 \mathrm{p}$.

6. Veresha R. Criminal and Legal Characteristics of Criminal Intent. Journal of Advanced Research in Law and Economics. 2016. № 21. P. 1881-1890.

7. Cruft R., Matthew H. Kramer. Crime, Punishment, and Responsibility: The Jurisprudence of Antony Duff. Oxford University Press, 2011. 408 p.

8. Бурдін В.М. Стадії вчинення злочину (кримінально-правове дослідження) : монографія. Львів, 2013. 303 с

9. Дурманов Н.Д. Стадии совершения преступления по советскому уголовному праву. Москва, 1955. $211 \mathrm{c}$.

10. Тихий В.П., Панов М.І. Злочин, його види та стадії : науково-практ. коментар. Київ, 2007. 37 с.

11. Антонян Ю.М., Еникеев М.И., Эминов В.Е. Психология преступления и наказания : монография. Москва, 2018. 399 с.
12. Lima G.F. Iter criminis: consumação e tentativa. Centro Universitário Toledo. Araçatuba, 2018. 56 p.

13. Козлов А.П. Учение о стадиях преступления. СПб, 2002. 351 с.

14. Пионтковский А.А. Курс советского уголовного права. Т. 2. Преступление. Москва, $1970.518 \mathrm{c}$

15. Литвишков В.М. Стадии совершения преступлений : монография. Краснодар, 2018. 98 с.

16. Маслак Н.В. Кримінальна відповідальність за готування до злочину : монографія. Харків, 2010. 232 с.

17. Гринь М.В. Неоконченное преступление : дисс. ... канд. юрид. наук: 12.00.08. Краснодар, 2003. 209 c

18. Федорак Л.М. Злочинний намір у кримінальному праві України. Вісник Верховного Суду Украӥни. 2015. № 11. С. 44-48.

19. Сафронов С.О. Ознаки наявності у особи злочинного наміру або задуму. Форум права. 2017. № 3. С. 199-203.

20. Бабий Н.А. Учение о стадиях преступления и неоконченных преступлениях : монография. Москва, 2017. 747 с.

21. Кримінальний кодекс України : зі змін. та допов. станом на 12 лют. 2019 р. / уклад., підгот. B.I. Тютюгін. Харків, 2019. 303 с.

22. Шевчук А.В. Стадії вчинення злочину : дис... канд. юрид. наук: 12.00.08. Чернівці, 2002. $181 \mathrm{c}$

23. Конституція України. Харків, 2019. 70 с.

The article deepens the doctrine of intent as part of a crime. It has been stated that the issues of intent are not sufficiently covered in the scientific literature. Also, in the theory of criminal law there is no unambiguous opinion about the formation (occurrence) of intent and its attribution to the part of the crime. Some scholars identify the intent as part of the crime, while others oppose its attribution to the stages of the crime. Therefore, separate coverage of this issue is a gap in modern science and has scientific novelty. This article is intended to fill this gap.

A crime committed intentionally is an act committed with direct or indirect intent. Deliberate crimes are the most dangerous crimes. At the same time, the vast majority of crimes, provided by the rules of criminal law, are among the intentional. It is noted that the initial stage of the crime is the appearance of intent, which at the initial stage often does not have any external manifestation. Before committing a certain criminal act in the mind of a person, a general idea of the essence of the crime, of the ways of its commission is formed, a psychological attitude to the future criminal act is formed, to the criminal result in the form of the desire to achieve a criminal purpose. When forming a deliberate mental activity of a person does not find its expression in the outside world, does not present a real danger for the object of the crime, at this stage there is no real threat of harm to the interests of the individual, society or state. Conscious activity of a person at the stage of intentional formation has no independent criminal legal value and is not punishable. However, if a person commits the following actions aimed at the realization of a previously established criminal intent and they constitute a socially dangerous act that causes harm or creates a real threat of harm to public relations, goods and interests protected by the right, that is, if a mental disorder is formed the act and its consequences find its external manifestation either at the stage of preparing for a crime or at the stage of intentional commission of actions (inaction) directly aimed at committing a crime Well, in this case the formation of intent should be recognized as the initial stage of the crime. It is established that the formation of intent and its detection in the obligatory presence of at least one of the following stages in the development of criminal activity should be attributed to the impunity stages of the development of crime. It is not necessary that all stages of criminal activity be punished. In this case, when it comes to an already completed crime, an important practical importance is the study of the formation of intent, which helps to uncover the essence of crime in the dynamics. It is noted that the prospect of further research in this direction is the problem of adequate legislative reflection of the danger of intent.

Key words: stage of a crime, uncompleted crime, completed crime, preparation for a crime, criminal behavior, criminal intent. 